\title{
Recuperação de estudos: Uma busca pela educação de qualidade
}

Recebido em 29.04.2015. Aprovado em 05.05. 2015 Avaliado pelo sistema double blind review

\author{
Flávia Gonçalves da Silva Mendes \\ cemariotamborindeguy@educacao.rj.gov.br \\ Colégio Estadual Mário Tamborindeguy - São Gonçalo - RJ - Brasil
}

\section{Resumo}

Um olhar mais aprofundado sobre o Colégio Estadual Mário Tamborindeguy mostrou alguns problemas que devem ser atacados para um melhor desempenho escolar dos alunos. Os últimos resultados das avaliações externas mostraram que a escola não consegue atingir as metas estabelecidas pelo MEC, medido através do Indice de Desenvolvimento da Educação Básica (IDEB) e do Sistema de Avaliação do Estado do Rio de Janeiro (SAERJ). Os resultados internos também mostraram que as disciplinas que mais reprovam em nossa unidade escolar são Língua Portuguesa e Matemática, principais disciplinas avaliadas nos exames externos. Constatação que a escola não vem fazendo um trabalho efetivo de recuperação de estudos.

As "Oficinas de Aprendizagem", aqui propostas, aliam o uso de tecnologias de informação e comunicação para despertar o interesse do aluno em participar e realizar com sucesso a recuperação de estudos. Nas oficinas, os alunos utilizarão o laboratório de informática da escola e terão acesso aos diversos materiais voltados para esse fim utilizando mídias próprias e uma plataforma especifica que visam junto trabalhar com 0 conteúdo de maneira diversificada e prazerosa. O projeto foi criado para auxiliar os alunos na busca pela recuperação de habilidades que deixaram de ser adquiridas no decorrer do processo de aprendizagem. 09 ano do Ensino Fundamental foi escolhido porque é um dos focos das avaliações externas e é avaliado com uma maior periodicidade. Além disso, percebemos que muitos alunos evadem ou pedem transferência nesta fase. Esses alunos precisam ser observados mais de perto porque devem permanecer e cursar o Ensino Médio em nossa unidade escolar.

Os objetivos estratégicos do projeto repousam sobre principais problemas apontados no diagnóstico da escola. São eles: Aumentar a quantidade de habilidades adquiridas em Língua Portuguesa e Matemática no 9 ano de escolaridade; diminuir a quantidade de professores e alunos em absenteísmo escolar; tornar as aulas de Língua Portuguesa e Matemática mais atrativas.

A escola possui um laboratório de informática pouco utilizado e com internet banda larga. $E$ como os alunos da nossa escola valorizam muito os recursos digitais e de internet, identifiquei nas oficinas de aprendizagem a oportunidade de unir esses fatores para aumentar o desempenho dos alunos nas disciplinas de Língua Portuguesa e Matemática. Portanto, o valor solicitado através de Edital que totalizam $\mathrm{R} \$ 75.382,88$ servirá para melhoria da infraestrutura desse espaço e sua modernização, para financiar a contratação de um profissional especializado em tecnologias de informação, elaboração de uma plataforma de aprendizagem única para este laboratório e capacitar os profissionais que utilizarão esse novo recurso. Como contrapartida, a escola pode oferecer 0 trabalho de toda uma equipe de profissionais especializados e uma estrutura adequada e aprazível para realização das oficinas de aprendizagem.

Palavras-chaves: Educação. Oficinas educacionais. Plano de empreendimento. Laboratório de informática. 


\section{Caracterização da escola}

O Colégio Estadual Mário Tamborindeguy fundado em1998 na cidade de São Gonçalo, Rio de Janeiro, atende a 396 alunos nas séries: $6^{\circ}$ ao $9^{\circ}$ ano do Ensino fundamental e Ensino Médio.

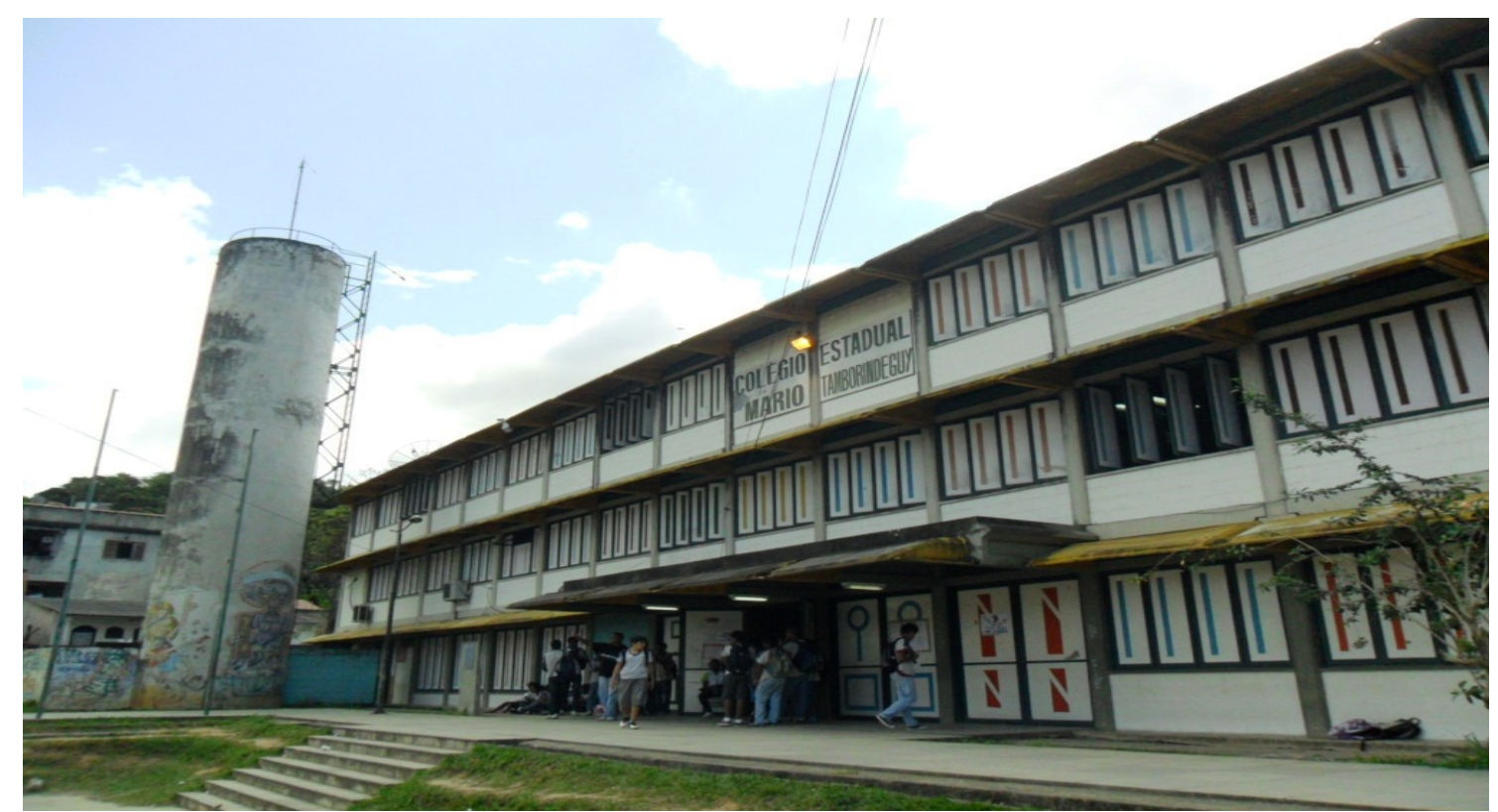

\section{Missão:}

Fomentar ensino de excelência capaz de contribuir com a formação de cidadãos preparados para a vida e para o mundo do trabalho. Pessoas capazes de atuar de forma ética e responsável com o outro e com o meio ambiente tornando-se menos vulneráveis as condições de criminalidade da comunidade onde vivem.

\section{Visão:}

Ser reconhecida como uma escola de qualidade em nossa cidade, capaz de alcançar as metas estabelecidas de crescimento para o IDEB, comprometida com a garantia de aprendizado eficiente e permanência dos alunos na escola.

\section{Instalações}

O Colégio Estadual Mário Tamborindeguy possui 18 salas disponíveis para a execução das aulas, 01 biblioteca ampla e com bom acervo, 01 laboratório de ciências, igualmente equipado e com recursos modernos para a realização da prática das ciências, 01 laboratório de informática com acesso a internet, 01 sala multimídia equipada com TV, som e projetor, 01 quadra esportiva, porém não muito preservada. Esse espaço é invadido constantemente por pessoas alheias a escola. A sala de professores é ampla e possui um computador com acesso a internet para que os professores possam planejar as suas aulas e compartilhar experiências entre si.

Além desses espaços, podemos contemplar toda a área administrativa. Direção, coordenação pedagógica, secretaria escolar. A escola possui cozinha e um refeitório grande e confortável para a realização das refeições. $O$ pátio é aberto, o que propicia muita interação entre os alunos no intervalo entre as aulas e recreio. Em dias de chuva, o fato de o pátio ser aberto causa grande transtorno. Os alunos amontoam-se pelos corredores e escadas. Os espaços escolares são bons e amplos. Com exceção de algumas salas de aulas do $2^{\circ}$ pavimento que estão com infiltrações sérias devido a um problema na cobertura da escola. 


\section{Recuperação de estudos: Uma busca pela educação de qualidade}

\section{Breve histórico}

O quadro a seguir apresenta a relação dos acontecimentos mais relevantes para a evolução da escola, desde a fundação até hoje.

\begin{tabular}{|l|l|}
\hline Ano & Acontecimentos relevantes \\
\hline 1998 & Fundação da escola \\
\hline 2004 & $\begin{array}{l}\text { Escola passa a abrigar provisoriamente uma escola municipal do Bairro, que desabou } \\
\text { devido a uma grande enchente. }\end{array}$ \\
\hline 2007 & A escola municipal finalmente deixa o prédio da escola. \\
\hline 2009 & $\begin{array}{l}\text { A escola deixa de atender progressivamente o Ensino Fundamental I, provocando uma } \\
\text { queda brutal na quantidade de alunos. }\end{array}$ \\
\hline 2010 & A escola começou a atender o Ensino Médio. \\
\hline
\end{tabular}

\section{Professores e funcionários}

A equipe é formada por 37 professores no quadro permanente distribuídos da seguinte forma:

\begin{tabular}{|l|l|}
\hline Disciplina / Área & Quant. de professores \\
\hline Língua Portuguesa & 6 \\
\hline Matemática & 4 \\
\hline Geografia & 3 \\
\hline História & 4 \\
\hline Artes & 2 \\
\hline Educação física & 2 \\
\hline Inglês & 2 \\
\hline Filosofia & 1 \\
\hline Sociologia & 1 \\
\hline Química & 1 \\
\hline Física & 1 \\
\hline Biologia & 1 \\
\hline Ciências Físicas e Biológicas & 4 \\
\hline Professor docente II & 5 \\
\hline Total & 37 \\
\hline
\end{tabular}

Do total de 37 professores, 32 estão em efetivo exercício docente, 2 estão atuando como diretores escolares, 01 coordenador pedagógico, 1 articulador pedagógico e 01 agente de leitura. Todo ano nós recebemos professores contratados para suprir a carência de professores da rede estadual, principalmente da disciplina 
Matemática. Além disso, a escola conta com 3 funcionários de apoio, sendo que 01 atua como secretário escolar, 01 agente de pessoal e 01 auxiliar de secretaria. 0 serviço de limpeza, portaria e preparo de alimentos é terceirizado e conta com uma equipe de 11 funcionários.

No quadro de professores, nós temos: 04 mestres, 02 doutorandos e 16 especialistas, os demais possuem licenciatura na área que atuam. 0 grupo procura atualizar-se. As diversas oportunidades de cursos e aprimoramento em serviço são aproveitadas.

\section{Perfil dos alunos}

Os alunos estão distribuídos por séries e turnos da seguinte maneira:

\begin{tabular}{|c|c|c|c|c|c|c|c|c|}
\hline \multirow[b]{2}{*}{ Série/Ano } & \multirow{2}{*}{$\begin{array}{l}\text { Média } \\
\text { de } \\
\text { idade }\end{array}$} & \multirow{2}{*}{$\begin{array}{l}\text { Total } \\
\text { de } \\
\text { alunos }\end{array}$} & \multicolumn{2}{|l|}{ Manhã } & \multicolumn{2}{|l|}{ Tarde } & \multicolumn{2}{|l|}{ Noite } \\
\hline & & & $\begin{array}{l}\mathrm{N}^{0} \\
\text { alunos }\end{array}$ & $\begin{array}{l}\mathrm{N}^{\circ} \\
\text { turmas }\end{array}$ & $\begin{array}{l}\mathrm{N}^{\mathrm{O}} \\
\text { alunos }\end{array}$ & $\begin{array}{l}\mathrm{N}^{0} \\
\text { turmas }\end{array}$ & $\begin{array}{l}\mathrm{N}^{0} \\
\text { alunos }\end{array}$ & $\begin{array}{l}\mathrm{N}^{0} \\
\text { turmas }\end{array}$ \\
\hline $6^{\circ}$ ano & $12 a$ & 32 & 32 & 1 & -- & - & - & - \\
\hline $7^{\circ}$ ano & $14 a$ & 42 & 42 & 2 & -- & -- & - & - \\
\hline $8^{\circ}$ ano & $15 a$ & 58 & 58 & 2 & -- & - & - & - \\
\hline $9^{\circ}$ ano & $16 a$ & 53 & 53 & 2 & -- & -- & - & - \\
\hline $1^{\circ} \mathrm{E} . \mathrm{M}$. & $17 a$ & 51 & 51 & 2 & -- & -- & - & - \\
\hline $2^{\circ}$ E.M. & $17 a$ & 23 & 23 & 1 & -- & -- & - & - \\
\hline $3^{\circ}$ E.M. & $18 a$ & 20 & 20 & 1 & -- & -- & - & - \\
\hline $1^{\circ}$ EM. (EJA) & N/A & 21 & - & - & -- & -- & 21 & 01 \\
\hline $2^{\circ}$ EM. (EJA) & $\mathrm{N} / \mathrm{A}$ & 26 & - & - & -- & -- & 26 & 01 \\
\hline $3^{\circ}$ EM. (EJA) & $\mathrm{N} / \mathrm{A}$ & 20 & - & - & -- & -- & 20 & 01 \\
\hline $4^{\circ} \mathrm{EM}$ (EJA) & $\mathrm{N} / \mathrm{A}$ & 12 & - & - & -- & -- & 12 & 01 \\
\hline TOTAL & - & & & & & & & \\
\hline
\end{tabular}

Os alunos da escola são bastante participativos nos projetos propostos pela unidade escolar. Como feiras, mostras e festivais. A escola vira uma festa em todos os eventos. Porém, os alunos não participam muito das atividades no contra turno como o Programa Mais Educação uma estratégia do Ministério da Educação para induzir a ampliação da jornada escolar e a organização curricular na perspectiva da Educação Integral e 0 Reforço Escolar criado pela Secretaria de Estado de Educação do Estado do Rio de Janeiro voltado para a recuperação de aprendizagem. Em conversa com os nossos alunos sobre 0 assunto, ouvimos deles como justificativa, o fato deles trabalharem no contra turno e participarem de programas de acesso ao ensino técnico e emprego como: Pronatec e Jovem Aprendiz.

Como a escola é localizada à beira da Rodovia, recebemos alunos da comunidade e de fora dela também. Alguns alunos têm envolvimento com o tráfico de drogas. 0 que sempre nos deixa em estado de alerta. Tanto para que eles não consumam, tanto para que eles não vendam a droga no interior da escola. As adolescentes também nos preocupam. Algumas engravidam cedo e acabam saindo da escola. Muitos alunos são agressivos e brigas ocasionais acontecem. Apesar disso, ainda temos espaço para o diálogo em nosso cotidiano. Os alunos ouvem e aceitam as intervenções da equipe escolar.

Os pais não comparecem em grande quantidade às nossas reuniões, porém quando são convocados, vão a escola saber sobre comportamento e notas dos seus filhos. Há um respeito entre a família e a escola e os 
pais valorizam as nossas comunicações entre escola e a casa que são bastante freqüentes.

\section{Características do entorno}

A comunidade onde a escola está inserida é afastada do centro da Cidade de São Gonçalo e faz parte da região metropolitana do Estado do Rio de Janeiro. A comunidade cresceu entorno da Rodovia Amaral Peixoto. Via importante de ligação entre os municípios da Região dos Lagos, São Gonçalo, Niterói e Rio de Janeiro. Os moradores do local são pessoas simples que acordam bastante cedo para o trabalho. Muitas famílias, tanto pai como mãe trabalham fora de casa. Esse trabalho normalmente fica em municípios vizinhos. Embora na comunidade existam comércios e algumas fábricas. A comunidade é bastante violenta. 0 tráfico de drogas é o principal problema observado. As incursões da polícia na comunidade provocam várias trocas de tiros, o que aumenta o clima de medo que envolve alunos e pais.

Há coleta de lixo e serviços de telefonia e internet. Porém em quantidade insuficiente. $O$ transporte é de fácil uso devido à localização próxima a Rodovia. Um posto de saúde atende à comunidade, mas, faltam médicos com frequência. São três escolas públicas: 02 da rede municipal, 01 da rede estadual e que atendem bem a comunidade. Não faltam vagas para os alunos. Existe uma creche municipal, porém faltam vagas para atender a todos que necessitam.

\section{Identificação do problema e da oportunidade}

A escola não conseguiu atingir a meta de IDEB projetada para o $9^{\circ}$ ano do Ensino Fundamental em 2013. Houve um crescimento tímido, porém insuficiente.

Em reunião pedagógica com a equipe de professores, alguns fatores foram levantados como possíveis causas desse resultado negativo. A falta de interesse dos alunos em realizar a avaliação (Prova Brasil). E a falta de participação demonstrada por alguns professores em realizar um trabalho voltado para as avaliações externas. A equipe pedagógica percebe também a resistência por parte dos professores em realizar a recuperação de estudos. E principalmente realizar essa recuperação de aprendizagem de forma diferenciada e atrativa.

O Índice de desenvolvimento da Educação Básica, o IDEB, e um importante instrumento na busca pela qualidade da educação. $O$ indicador é calculado através dos dados de aprovação escolar, obtidos pelo Censo Escolar e pelo desempenho obtido nas avaliações do Inep. E um orientador das ações pedagógicas desenvolvidas pela escola.

\section{IDEB}

Resultado IDEB para $9^{\circ}$ ano

\begin{tabular}{|l|l|l|l|l|l|l|l|l|l|}
\hline ANO & 2005 & 2007 & 2009 & 2011 & 2013 & 2015 & 2017 & 2019 & 2021 \\
\hline Metas projetadas & - & - & 3,4 & 3,6 & 3,9 & 4,3 & 4,5 & 4,8 & 5,1 \\
\hline Ideb observado & & 3,3 & 1,7 & 3,2 & 3,4 & - & - & - & - \\
& & & & & & & & & \\
\hline
\end{tabular}

Fonte: INEP

\section{Avaliação estadual}

\section{Para RJ}

O Sistema de Avaliação do Estado do Rio de Janeiro (Saerj) foi criado em 2008 com o objetivo de analisar 0 desempenho dos alunos da rede estadual no $5^{\circ}, 9^{\circ}$ e $3^{\circ}$ ano do ensino médio. Depois de realizada a avaliação, é emitida uma Revista Pedagógica informando às escolas a sua posição em relação à proficiência. E a posição da escola em relação ao Estado do Rio de Janeiro e em relação à Diretoria Regional Pedagógica da qual a escola faz parte. 
$9^{\circ}$ ano do Ensino fundamental Regular

Resultados da escola

Língua Portuguesa

\begin{tabular}{|l|l|l|l|l|l|}
\hline Edição & $\begin{array}{l}\text { Proficiência } \\
\text { Média }\end{array}$ & Baixo & Intermediário & Adequado & Avançado \\
\hline 2013 & 240,7 & $23,3 \%$ & $50,0 \%$ & $20,0 \%$ & $6,7 \%$ \\
\hline
\end{tabular}

Resultados do Estado do Rio de Janeiro

\begin{tabular}{|l|l|l|l|l|l|}
\hline Edição & $\begin{array}{l}\text { Proficiência } \\
\text { Média }\end{array}$ & Baixo & Intermediário & Adequado & Avançado \\
\hline 2013 & 236,8 & $24,7 \%$ & $50,9 \%$ & $21,0 \%$ & $3,4 \%$ \\
\hline
\end{tabular}

Resultados da Diretoria Regional Pedagógica Metropolitana II

\begin{tabular}{|l|l|l|l|l|l|}
\hline Edição & $\begin{array}{l}\text { Proficiência } \\
\text { Média }\end{array}$ & Baixo & Intermediário & Adequado & Avançado \\
\hline 2013 & 229,8 & $29,2 \%$ & $50,0 \%$ & $18,2 \%$ & $2,6 \%$ \\
\hline
\end{tabular}

$9^{\circ}$ ano do Ensino fundamental Regular

Resultados da escola

Matemática

\begin{tabular}{|l|l|l|l|l|l|}
\hline Edição & $\begin{array}{l}\text { Proficiência } \\
\text { Média }\end{array}$ & Baixo & Intermediário & Adequado & Avançado \\
\hline 2013 & 226,1 & $40,0 \%$ & $60,0 \%$ & $0,0 \%$ & $0,0 \%$ \\
\hline
\end{tabular}

Resultados do Estado do Rio de Janeiro

\begin{tabular}{|l|l|l|l|l|l|}
\hline Edição & $\begin{array}{l}\text { Proficiência } \\
\text { Média }\end{array}$ & Baixo & Intermediário & Adequado & Avançado \\
\hline 2013 & 241,5 & $35,6 \%$ & $55,0 \%$ & $8,4 \%$ & $1,1 \%$ \\
\hline
\end{tabular}

Resultados da Diretoria Regional Pedagógica Metropolitana II

\begin{tabular}{|l|l|l|l|l|l|}
\hline Edição & $\begin{array}{l}\text { Proficiência } \\
\text { Média }\end{array}$ & Baixo & Intermediário & Adequado & Avançado \\
\hline 2013 & 234,1 & $40,7 \%$ & $53,5 \%$ & $5,4, \%$ & $0,4 \%$ \\
\hline
\end{tabular}

Os resultados do SAERJ demonstraram que na disciplina de Língua Portuguesa, a escola obteve uma média maior que a demonstrada pelo Estado do Rio de Janeiro e pela Diretoria Regional Metropolitana II. Porém, a escola está longe de estar em um nível adequado de desempenho. Os índices mostram que $23,3 \%$ dos 
nossos alunos estão no nível baixo e $50 \%$ no nível intermediário. Apenas $20 \%$ estão no nível adequado e 6,7 no nível avançado.

Em Matemática, a situação é um pouco pior, a escola está abaixo da média obtida pelo Estado do Rio de Janeiro e da Diretoria Regional Metropolitana II. Os índices mostram que $40.0 \%$ dos nossos alunos estão no nível intermediário e 60\% no nível intermediário. Com base nesse resultado, não temos índice de alunos no nível adequado e avançado de aprendizagem.

Esses dados, aliados ao resultado baixo obtido no último IDEB, apontam para uma necessidade urgente de recuperação de aprendizagem e mudança de estratégias de aprendizagem.

Avaliações e relatórios internos

Os resultados abaixo demonstram situações que devem ser observadas com atenção e servem para apontar onde devemos focar o trabalho pedagógico de nossa escola. Em todos os anos de escolaridade, os maiores índices de reprovação são nas disciplinas de Língua Portuguesa e Matemática. Embora haja exceções, como no caso do $7^{\circ}$ ano em que 20 alunos foram reprovados em língua estrangeira. Muito acima dos valores apontados nas disciplinas de Língua Portuguesa e Matemática.

O índice de reprovação em Língua Portuguesa e Matemática mostra que os alunos sentem mais dificuldades em aprender nestas disciplinas, o que acaba refletindo nas avaliações externas.

É possível perceber que há um acréscimo da quantidade de alunos que evadiram ou solicitaram transferência da escola à medida que os anos de escolaridade avançam. No $9^{\circ}$ ano, perdemos 31 alunos. Público fundamental para o fortalecimento do Ensino Médio. A nossa escola tem uma capacidade para atender mais alunos que atende atualmente e, perder alunos, tanto por evasão ou por transferência também nos preocupa. Precisamos manter os alunos na escola e receber mais alunos nos próximos anos. Tornou-se uma questão de sobrevivência da escola, aumentar a quantidade de alunos.

\begin{tabular}{|c|c|c|c|c|c|c|c|}
\hline Série/Ano & $\begin{array}{l}\text { Matrículas } \\
\text { iniciais }\end{array}$ & Evasão & Transf. & $\begin{array}{l}\text { Matrículas } \\
\text { finais }\end{array}$ & Disciplinas & Aprov. & Reprov. \\
\hline \multirow{8}{*}{$6^{\circ}$ ano } & \multirow{8}{*}{33} & \multirow{8}{*}{02} & \multirow{8}{*}{06} & \multirow{8}{*}{25} & Português & 20 & 05 \\
\hline & & & & & Matemática & 21 & 04 \\
\hline & & & & & História & 24 & 01 \\
\hline & & & & & Geografia & 25 & 00 \\
\hline & & & & & Ciências & 22 & 03 \\
\hline & & & & & L. Estrangeira & 25 & 00 \\
\hline & & & & & Ed. Física & 25 & 00 \\
\hline & & & & & Artes & 18 & 07 \\
\hline \multirow{8}{*}{$7^{\circ}$ ano } & \multirow{8}{*}{60} & \multirow{8}{*}{04} & \multirow{8}{*}{11} & \multirow{8}{*}{45} & Português & 33 & 12 \\
\hline & & & & & Matemática & 46 & 09 \\
\hline & & & & & História & 40 & 06 \\
\hline & & & & & Geografia & 44 & 01 \\
\hline & & & & & Ciências & 43 & 02 \\
\hline & & & & & L. Estrangeira & 25 & 20 \\
\hline & & & & & Ed. Física & 42 & 03 \\
\hline & & & & & Artes & 37 & 08 \\
\hline
\end{tabular}


Flávia Gonçalves da Silva Mendes

\begin{tabular}{|c|c|c|c|c|c|c|c|}
\hline \multirow{8}{*}{$8^{\circ}$ ano } & \multirow{8}{*}{64} & \multirow{8}{*}{04} & \multirow{8}{*}{10} & \multirow{8}{*}{50} & Português & 38 & 12 \\
\hline & & & & & Matemática & 28 & 22 \\
\hline & & & & & História & 43 & 07 \\
\hline & & & & & Geografia & 42 & 08 \\
\hline & & & & & Ciências & 42 & 08 \\
\hline & & & & & L. Estrangeira & 35 & 15 \\
\hline & & & & & Ed. Física & 48 & 02 \\
\hline & & & & & Artes & 39 & 11 \\
\hline \multirow{8}{*}{$9^{\circ}$ ano } & \multirow{8}{*}{72} & \multirow{8}{*}{14} & \multirow{8}{*}{17} & \multirow{8}{*}{41} & Português & 26 & 15 \\
\hline & & & & & Matemática & 24 & 17 \\
\hline & & & & & História & 38 & 03 \\
\hline & & & & & Geografia & 33 & 08 \\
\hline & & & & & Ciências & 32 & 09 \\
\hline & & & & & L. Estrangeira & 31 & 10 \\
\hline & & & & & Ed. Física & 40 & 1 \\
\hline & & & & & Artes & 39 & 2 \\
\hline \multirow{12}{*}{$1^{\circ}$ ano E.M. } & \multirow{12}{*}{54} & \multirow{12}{*}{05} & \multirow{12}{*}{08} & \multirow{12}{*}{41} & Português & 30 & 11 \\
\hline & & & & & Matemática & 27 & 14 \\
\hline & & & & & História & 32 & 09 \\
\hline & & & & & Geografia & 35 & 06 \\
\hline & & & & & Biologia & 28 & 13 \\
\hline & & & & & L. Estrangeira & 32 & 09 \\
\hline & & & & & Ed. Física & 38 & 03 \\
\hline & & & & & Artes & -- & -- \\
\hline & & & & & Química & 33 & 08 \\
\hline & & & & & Física & 36 & 05 \\
\hline & & & & & Filosofia & 28 & 13 \\
\hline & & & & & Sociologia & 34 & 07 \\
\hline \multirow{11}{*}{$2^{\circ}$ ano E.M. } & \multirow{11}{*}{24} & \multirow{11}{*}{02} & \multirow{11}{*}{02} & \multirow{11}{*}{20} & Português & 18 & 02 \\
\hline & & & & & Matemática & 15 & 05 \\
\hline & & & & & História & 17 & 03 \\
\hline & & & & & Geografia & 19 & 01 \\
\hline & & & & & Biologia & 18 & 02 \\
\hline & & & & & L. Estrangeira & 17 & 03 \\
\hline & & & & & Ed. Física & 19 & 01 \\
\hline & & & & & Artes & 17 & 03 \\
\hline & & & & & Química & 20 & 00 \\
\hline & & & & & Física & 19 & 01 \\
\hline & & & & & Filosofia & 18 & 02 \\
\hline
\end{tabular}


Recuperação de estudos: Uma busca pela educação de qualidade

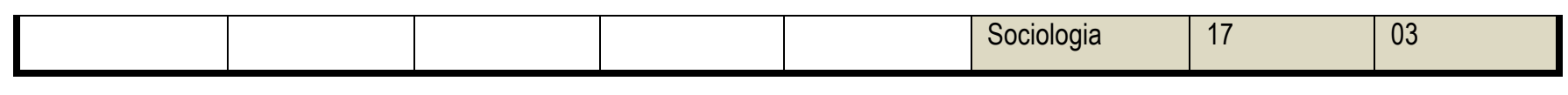

\begin{tabular}{|c|c|c|c|c|c|c|c|}
\hline \multirow{12}{*}{$3^{\circ}$ ano E.M. } & \multirow{12}{*}{14} & \multirow{12}{*}{01} & \multirow{12}{*}{04} & \multirow{12}{*}{09} & Português & 09 & 00 \\
\hline & & & & & Matemática & 09 & 00 \\
\hline & & & & & História & 09 & 00 \\
\hline & & & & & Geografia & 09 & 00 \\
\hline & & & & & Biologia & 09 & 00 \\
\hline & & & & & L. Estrangeira & 09 & 00 \\
\hline & & & & & Ed. Física & 09 & 00 \\
\hline & & & & & Artes & 09 & 00 \\
\hline & & & & & Química & 09 & 00 \\
\hline & & & & & Física & 09 & 00 \\
\hline & & & & & Filosofia & 09 & 00 \\
\hline & & & & & Sociologia & 09 & 00 \\
\hline \multirow{12}{*}{$\begin{array}{l}\text { NEJA }^{*} \\
1^{\circ} \text { ano E.M. }\end{array}$} & \multirow{12}{*}{14} & \multirow{12}{*}{02} & \multirow{12}{*}{04} & \multirow{12}{*}{08} & Português & 07 & 01 \\
\hline & & & & & Matemática & 07 & 01 \\
\hline & & & & & História & 07 & 01 \\
\hline & & & & & Geografia & 07 & 01 \\
\hline & & & & & Biologia & - & _- \\
\hline & & & & & L. Estrangeira & - & - \\
\hline & & & & & Ed. Física & - & _- \\
\hline & & & & & Artes & - & _- \\
\hline & & & & & Química & - & _- \\
\hline & & & & & Física & - & - \\
\hline & & & & & Filosofia & - & - \\
\hline & & & & & Sociologia & - & - \\
\hline \multirow{12}{*}{$\begin{array}{l}\text { NEJA }{ }^{*} \\
2^{\circ} \text { ano E.M. }\end{array}$} & \multirow{12}{*}{25} & \multirow{12}{*}{02} & \multirow{12}{*}{03} & \multirow{12}{*}{20} & Português & 15 & 05 \\
\hline & & & & & Matemática & 13 & 07 \\
\hline & & & & & História & -- & - \\
\hline & & & & & Geografia & --- & --- \\
\hline & & & & & Biologia & -- & -- \\
\hline & & & & & L. Estrangeira & -- & --- \\
\hline & & & & & Ed. Física & --- & --- \\
\hline & & & & & Artes & -- & --- \\
\hline & & & & & Química & 14 & 06 \\
\hline & & & & & Física & 11 & 09 \\
\hline & & & & & Filosofia & --- & --- \\
\hline & & & & & Sociologia & --- & --- \\
\hline
\end{tabular}




\begin{tabular}{|c|c|c|c|c|c|c|c|}
\hline \multirow{12}{*}{$\begin{array}{l}\text { EJA } \\
3^{\circ} \text { ano E.M. }\end{array}$} & \multirow{12}{*}{35} & \multirow{12}{*}{04} & \multirow{12}{*}{0} & \multirow{12}{*}{31} & Português & 31 & 00 \\
\hline & & & & & Matemática & 30 & 01 \\
\hline & & & & & História & 31 & 00 \\
\hline & & & & & Geografia & 31 & 00 \\
\hline & & & & & Biologia & 30 & 01 \\
\hline & & & & & L. Estrangeira & 30 & 01 \\
\hline & & & & & Ed. Física & 31 & 00 \\
\hline & & & & & Artes & 30 & 01 \\
\hline & & & & & Química & 31 & 00 \\
\hline & & & & & Física & 30 & 01 \\
\hline & & & & & Filosofia & 30 & 01 \\
\hline & & & & & Sociologia & 31 & 00 \\
\hline
\end{tabular}

A pesquisa de satisfação realizada na escola apontou para alguns pontos interessantes e que complementam nosso diagnóstico. A pesquisa teve como público alvo, os alunos do Ensino Médio Regular. Um total de 96 alunos respondeu o questionário. Todos os alunos desse segmento. As perguntas relacionadas diretamente a aprendizagem foram separadas das demais. As opções dadas para respostas dos alunos foram, boa, regular, excelente, ruim e péssimo. Quando perguntados sobre como aos alunos avaliam as aulas dos professores, $51 \%$ responderam que acham boas. Em relação ao material didático e os recursos utilizados em sala de aula, apenas $38 \%$ consideram bons. A biblioteca foi considerada excelente por $46 \%$ e boa por $34 \%$ dos alunos.

Os programas como o Mais Educação e Reforço escolar foram considerados bons por $46 \%$ dos alunos. 0 ensino ofertado pela a escola é considerado bom por $56 \%$ dos nossos alunos.

Os professores em reuniões pedagógicas reclamam muito da falta de interesse dos alunos em aprender. Que os alunos chegam às aulas após o início das mesmas ou mesmo a partir da segunda aula. Não realizam as atividades propostas para casa e não realizam a recuperação de estudos com seriedade. Os professores apontam mais, a falta de perspectiva de futuro por parte dos alunos. No ano de 2014, elaboramos projetos voltados para a orientação para o mundo do trabalho para estabelecer essa relação direta entre a escola e 0 trabalho.

\section{Principais problemas identificados}

Após a análise de resultados obtidos pela escola nas últimas avaliações externas e levando em consideração a opinião de alunos, professores e equipe técnica pedagógica da escola foi possível identificar alguns problemas que devem ser o foco do trabalho pedagógico e administrativo da escola e que acreditamos ter uma relação direta com a aprendizagem.

O principal problema observado foi o baixo desempenho nas avaliações externas. Não conseguimos crescer nos resultados e alcançar as metas projetadas para o IDEB. E em relação ao SAERJ, avaliação aplicada pelo Governo do Estado do Rio de Janeiro, também ficamos abaixo do nível adequado de aprendizagem, medido pela proficiência nas disciplinas de Língua Portuguesa e Matemática.

Os relatórios internos também apontam que as disciplinas que mais reprovam em nossa unidade escolar são Língua Portuguesa e Matemática.

A nossa escola tem uma capacidade de atendimento bem maior do que atende atualmente. Além de não receber muitos alunos novos, muitos alunos pedem transferência e evadem. $O$ que nos faz questionar, como proceder para que não percamos mais alunos e que a nossa escola se torne mais atraente.

Outro fator preocupante é a falta de interesse dos alunos apontada pelos professores. Tanto em realizar a recuperação de estudos, como pelos estudos em si e pelo próprio futuro. 
Os alunos e equipe técnicos pedagógica apontam que o material didático e recursos utilizados nas aulas não são muito atrativos. Na fala dos professores também percebemos a falta de interesse em realizar um trabalho efetivo de recuperação de aprendizagem.

\section{Matriz GUT}

\begin{tabular}{|l|l|l|l|l|l|}
\hline Problemas & G & U & T & GxUxT & Prioridade \\
\hline $\begin{array}{l}\text { Baixo desempenho nas avaliações externas } \\
\text { SAERJ e Prova Brasil }\end{array}$ & 5 & 4 & 4 & 80 & $1^{0}$ \\
\hline Muitas transferências e evasão escolar & 4 & 5 & 2 & 40 & $4^{0}$ \\
\hline $\begin{array}{l}\text { Baixo desempenho na recuperação paralela } \\
\text { de estudos }\end{array}$ & 4 & 4 & 4 & 64 & $2^{0}$ \\
\hline Material didático pouco atrativo & 4 & 3 & 3 & 36 & $5^{\circ}$ \\
\hline Pouco interesse na aprendizagem & 4 & 4 & 3 & 48 & $3^{0}$ \\
\hline
\end{tabular}

\section{Detalhamento do problema}

Utilizou-se o Diagrama de Causa e Efeito para detalhar o problema:

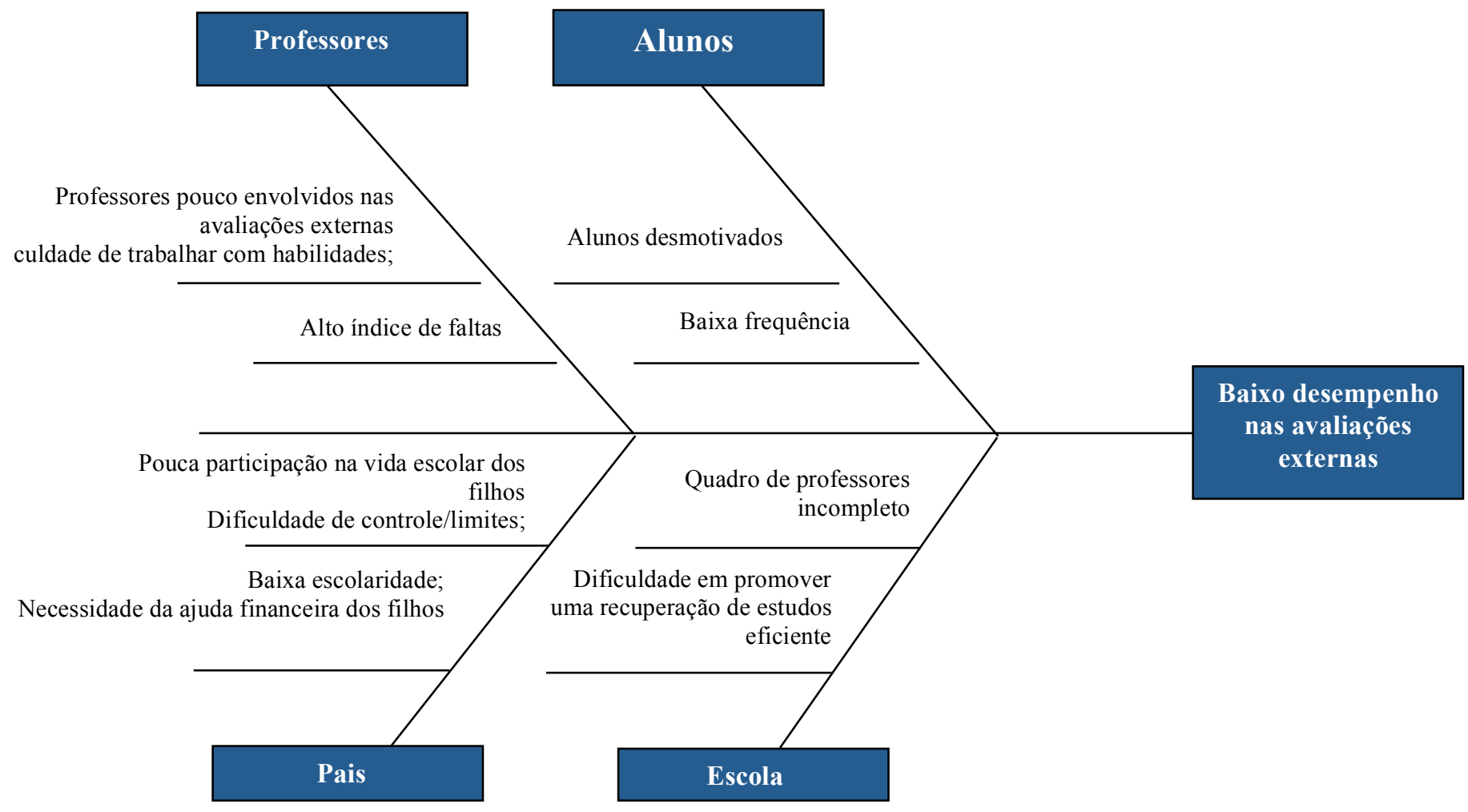




\section{Análise SWOT}

A partir das pesquisas realizadas pela equipe escolar e das discussões sobre o contexto da escola, foi desenvolvida a seguinte Matriz SWOT:

\begin{tabular}{|c|c|c|}
\hline & Aspectos favoráveis & Aspectos desfavoráveis \\
\hline & FORÇAS & FRAQUEZAS \\
\hline 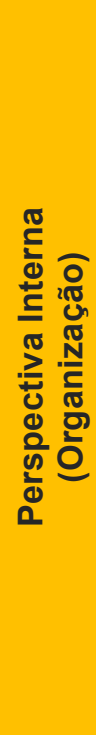 & $\begin{array}{l}\text { Facilidade de trabalhar em equipe e nos } \\
\text { mais diversos projetos; } \\
\text { Professores e equipe técnico-pedagógica } \\
\text { atualizada e ativa na participação de cursos } \\
\text { de formação continuada; } \\
\text { Ambiente agradável e infraestrutura } \\
\text { equipada e funcional com diversos } \\
\text { laboratórios. } \\
\text { Acesso à internet Banda Larga } \\
\text { O Programa Mais Educação e o Reforço } \\
\text { Escolar. }\end{array}$ & $\begin{array}{l}\text { Alto índice de atrasos e faltas; } \\
\text { Falta de um trabalho focado nas avaliações } \\
\text { externas e na recuperação de estudos; } \\
\text { Aulas pouco atrativas; } \\
\text { Professores pouco envolvidos com as } \\
\text { avaliações externas e recuperação de } \\
\text { estudos; }\end{array}$ \\
\hline \multirow[b]{2}{*}{ 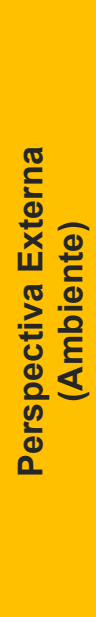 } & OPORTUNIDADES & AMEAÇAS \\
\hline & $\begin{array}{l}\text { Fábricas locais e Ong's. } \\
\text { A presença do Sest/Senat órgão integrante } \\
\text { do Sistema S que oferecem cursos } \\
\text { profissionalizantes e parceira da escola, } \\
\text { oferecendo vagas para os alunos e } \\
\text { funcionários. } \\
\text { Alguns alunos fazem cursos } \\
\text { profissionalizantes no contra turno }\end{array}$ & $\begin{array}{l}\text { Tráfico de drogas e violência; } \\
\text { Os alunos têm necessidade de } \\
\text { complementar a renda familiar e muitos } \\
\text { trabalham no contra turno. }\end{array}$ \\
\hline
\end{tabular}

A matriz SWOT ou FOFA da escola demonstra um equilíbrio entre forças e fraquezas. A equipe de professores se mantém estudiosa e tem muita facilidade em desenvolver projetos coletivos, porém ainda não estabelece como foco do trabalho, a realização das avaliações externas e recuperação de estudos. Ainda encontramos resistência em relação a essas avaliações e a recuperação de estudos. A resistência existe quando o professor não modifica a sua maneira de aplicar os conteúdos. Mesmo existindo farto material disponível em formato digital, inclusive no site da SEEDUC e no Portal CAED, que elabora as provas para 0 Estado do Rio de Janeiro, sendo possível consultar questões e elaborar exercícios voltados para 0 desenvolvimento das habilidades exigidas nestas avaliações. $O$ objetivo de melhorar nas avaliações externas passa obrigatoriamente em melhorar o desempenho interno, que também esta abaixo do esperado. Alguns 
professores ainda não utilizam os recursos disponíveis na escola, como, Data show, televisão, laboratório de informática e de Ciências. E os alunos reclamam de aulas pouco atrativas. $O$ absenteísmo escolar é um problema que também deve ser combatido. Há bastantes afastamentos e faltas entre os professores.

Como ameaça, podemos perceber a violência no entorno escolar. Alguns pais não deixam os seus filhos participarem de atividades elaboradas no contra turno. Devido a um problema já citado, que é o tráfico de drogas local. $E$, além disso, muitos alunos não têm disponibilidade porque trabalham ou fazem cursos profissionalizantes no contra turno. Sendo que é possível perceber esse fato com mais freqüência no Ensino Médio.

\section{Ações corretivas}

Visando preparar a organização para o desenvolvimento do projeto, no intuito combater as fraquezas e reduzir os possíveis impactos das ameaças, foram definidas as seguintes ações:

Desenvolver ações voltadas para a recuperação de estudos, utilizando o laboratório de informática e o acesso amplo à internet para realização de atividades voltadas para as habilidades não adquiridas no decorrer do processo de aprendizagem;

Solicitar em Universidades ou contratar um profissional que possa estar desenvolvendo junto aos professores um trabalho para diminuir ou acabar com o absenteísmo escolar, conscientizando a equipe dos danos causados a todos e principalmente aos alunos por essa prática;

Colocar em ação, um cronograma em que toda a escola utilize os laboratórios disponíveis em forma de rodízio para que eles não sejam furtados do direito a uma aprendizagem significativa e diversificada.

\section{Oportunidade identificada}

O principal problema identificado é o baixo desempenho nas avaliações externas, que refletem de certa maneira, o baixo desempenho das avaliações internas. Em análise de relatórios internos de aprendizagem, foi possível constatar que as disciplinas que mais reprovam são as de Língua Portuguesa e Matemática. A ação urgente passa a ser a recuperação de aprendizagem dos alunos com intuito de melhorar os índices nas avaliações externas e internas da escola.

A proposta é uma ação permanente de controle de aprendizagem voltada para $09^{\circ}$ ano do Ensino Fundamental. As disciplinas contempladas são Língua Portuguesa e Matemática. E o local escolhido é a sala de informática da escola. Os professores devem enviar a equipe técnica pedagógica um relatório constando as principais habilidades a serem desenvolvidas pelas oficinas de aprendizagem de maneira individualizada. $O$ acompanhamento individualizado dos alunos do 9 ano auxiliará também no controle da evasão escolar. $A$ formação de grupos de estudo onde os alunos, professores e estagiários de universidades seriam monitores.

O material seria elaborado pelos professores das disciplinas de Língua Portuguesa e Matemática em uma mídia, utilizando o conteúdo disponível no site da SEEDUC e CAED e materiais próprios, com as devidas soluções das atividades em anexo e seria armazenada na escola. $O$ aluno monitor escolhido ou voluntário utilizará esse material nas oficinas de aprendizagem. $O$ aluno monitor teria uma pontuação que poderia variar de 0 a 2 pontos pela sua participação na atividade, o que serviria de estímulo para a sua participação. As oficinas de aprendizagem seriam supervisionadas pela coordenadora pedagógica ou articuladora pedagógica e em caso de ausências, pelo diretor geral ou adjunto escolar. Os relatórios e atividades desenvolvidas serão enviados para o e-mail do professor. As oficinas de aprendizagem serão obrigatórias aos alunos com dificuldade de aprendizagem nestas disciplinas e com rendimento baixo no Saerjinho, avaliação diagnóstica bimestral aplicada pela Secretaria de Estado de Educação. A sala de informática e 0 uso de mídias foram escolhidos para incentivar o uso de tecnologias na aprendizagem e tornar as oficinas mais atraentes.

0 projeto envolve todos da equipe pedagógica e também os alunos. Busca desenvolver a conscientização dos pais da importância do projeto para a vida do seu filho. E aumenta a responsabilidade de todos sobre a aprendizagem escolar. Atualmente, a recuperação de estudos em nossa unidade escolar fica a cargo apenas do professor. 
A idéia principal da proposta é que a recuperação de estudos seja o foco do trabalho escolar. Que os alunos tenham atenção individualizada em suas dificuldades escolares e ainda que a escola tenha um maior comprometimento com o sucesso escolar de cada um. Acesso, qualidade na educação ofertada e permanência dos alunos na escola andem juntas. A implementação das oficinas visa promover 0 alcance das metas estabelecidas para as principais avaliações externas e melhorar o desempenho interno nas disciplinas de Língua Portuguesa e Matemática até o final do ano de 2017.

\section{Detalhamento do produto/serviço e/ou processo}

As oficinas de aprendizagem com uso de tecnologias de informação e comunicação propostas aqui visam despertar o interesse do aluno em participar e realizar com sucesso a recuperação de estudos. Nas oficinas, os alunos utilizarão o laboratório de informática da escola e terão acesso a diversos materiais voltados para esse fim utilizando mídias próprias e uma plataforma especifica que juntos visam trabalhar com o conteúdo de maneira diversificada e prazerosa. Na busca pela recuperação de habilidades que deixaram de ser adquiridas no decorrer do processo de aprendizagem.

Os professores das disciplinas de Língua Portuguesa e Matemática ficarão responsáveis por preparar 0 material em mídias próprias, como; CDs, DVDs, Pen drive com auxilio de um técnico especializado. A lousa digital também será utilizada nas oficinas, principalmente para a capacitação de professores e estagiários e voluntários. O técnico em tecnologias elaborará uma plataforma de aprendizagem com o material produzido. Essa plataforma será distribuída em rede interna no laboratório de informática. 0 aluno poderá acessar 0 conteúdo das disciplinas elencadas neste projeto e ter acesso aos exercícios, documentários e vídeos, inclusive no you tube. $\mathrm{O}$ aluno ao final da oficina enviará o trabalho para o professor por email.

O aluno terá a sua disposição, sempre um responsável para auxiliá-lo em suas dúvidas e no uso da plataforma. Como também ensinar as ferramentas básicas como fazer download e upload e uso de emails. 0 aluno monitor, o estagiário de universidade ou professor voluntário são as pessoas previstas para prestar esse auxílio. Apesar de ser uma ambiente de aprendizagem, nesse momento, ainda não contemplaremos a tutoria on line ou troca de experiências entre os alunos e professores de forma dinâmica. Serão duas oficinas semanais presenciais, uma para cada disciplina.

Os professores da turma junto à coordenação acompanharão a freqüência e o envio dos trabalhos elaborados neste espaço ao professor como também a liberação do aluno das oficinas. 0 projeto prevê uma rotatividade de alunos durante todo a execução do projeto.

\section{Foco do projeto}

Série ou conjunto de séries beneficiadas: $9^{\circ}$ ano de escolaridade do ensino fundamental

Disciplina ou conjunto de disciplinas trabalhadas: Português e Matemática

\section{Etapas do projeto}

O projeto será composto pelas seguintes etapas:

\section{Etapa 1 - Preparando as oficinas de aprendizagem}

Objetivo: Elaborar material adequado para as oficinas de aprendizagem incluindo a plataforma de aprendizagem e tornando-a funcional aos profissionais envolvidos no projeto.

Impacto na aprendizagem: não previsto nesta etapa

Atividades a serem realizadas: encontro com os professores para elaboração do material a ser utilizado, solicitar a presença de um especialista em tecnologias de informação e comunicação e montagem de plataforma de aprendizagem para o auxilio aos professores e execução do trabalho na escola. Oferecer capacitação aos profissionais envolvidos no projeto.

\section{Atividade 1.1}

Descrição: Encontros com os professores para elaboração do material a ser utilizado nas oficinas de aprendizagem. 
Duração: 01 mês

Recursos necessários: sala apropriada, mídias removíveis.

Equipe envolvida: especialista em TICs e montagem de plataforma de aprendizagem, professores de Língua Portuguesa e Matemática, coordenadores e diretores.

\section{Atividade 1.2}

Descrição: Montagem da plataforma de aprendizagem e reforma do laboratório de informática da escola, incluindo atualização de softwares e hardwares.

Duração: 01 mês

Recursos necessários: laboratório de informática, hardwares e softwares, mídias removíveis, acesso a internet.

Equipe envolvida: Especialista em TICs e diretores escolares.

\section{Atividade 1.3}

Descrição: Capacitação de professores, coordenadores pedagógicos e direção escolar para uso das oficinas de aprendizagem e auxilio aos estudantes.

Duração: 01 mês

Equipe envolvida: professores, coordenadores pedagógicos, direção escolar.

\section{Etapa 2 - Identificando necessidades e executando o projeto}

Objetivo: Identificar os alunos que deixaram de desenvolver as habilidades necessárias nas disciplinas contempladas pelo projeto a cada 15 dias.

Impacto na aprendizagem: Permitir que os alunos com necessidades de acompanhamento especial sejam identificados e comecem a freqüentar as oficinas de aprendizagem praticamente no momento em que as dificuldades surgem. Dessa forma esperamos que haja recuperação de estudos em tempo real.

Atividades a serem realizadas: triagem dos alunos que necessitam participar das oficinas de aprendizagem e envio a coordenação pedagógica, a coordenação pedagógica informará ao aluno e a família o dia e o horário em que o aluno devera comparecer para participar da oficina de aprendizagem, realização das oficinas de aprendizagem.

\section{Atividade 2.1}

Descrição: Os professores devem enviar a coordenação os alunos acompanhados de uma ficha individual com as habilidades a serem desenvolvidas nas oficinas assim que forem percebidas as lacunas no desenvolvimento da aprendizagem;

Duração: 01 a 03 anos

Recursos necessários: fichas de papel A4 individuais

Equipe envolvida: Professores e coordenadores pedagógicos

\section{Atividade 2.2}

Descrição: Oficinas de aprendizagem. As oficinas serão realizadas no laboratório de informática, utilizando mídias apropriadas para o desenvolvimento das habilidades e acesso a internet.

\section{Duração: 01 a 03 anos}

Recursos necessários: laboratório de informática, internet, mídias com conteúdo a ser desenvolvido e uso da 
plataforma.

Equipe envolvida: Professores da escola, coordenação pedagógica, professores voluntários, estagiários de universidades parceiras e alunos monitores.

\section{Etapa 3 - Acompanhamento os resultados obtidos com o projeto}

Objetivo: Avaliar a capacidade do projeto em melhorar o desempenho dos alunos nas avaliações externas e internas

Impacto na aprendizagem: a possibilidade de melhorar ou ampliar o projeto durante o seu tempo de duração.

Atividades a serem realizadas: análise de resultados e relatórios internos bimestralmente incluindo a freqüência e o rendimento dos alunos, análise do Saerjinho (avaliação diagnóstica bimestral aplicada nas escolas pela Secretaria de Estado de Educação). Oficinas de realização do Saerjinho com os alunos que obtiveram baixo rendimento.

\section{Atividade 3.1}

Descrição: Acompanhamento dos resultados obtidos pelos alunos participantes do projeto

Duração: Bimestralmente

Recursos necessários: papéis, mídias removíveis.

Equipe envolvida: professores, coordenadores pedagógicos, secretário escolar, gestor escolar.

\section{Atividade 3.2}

Descrição: Análise das avaliações diagnósticas (saerjinho) realizadas pelos alunos.

Duração: Bimestralmente

Recursos necessários: Provas externas realizadas

Equipe envolvida: Professores e coordenadores.

\section{Atividade 3.3}

Descrição: Oficinas especiais pós realização do Saerjinho para os alunos que obtiveram baixo rendimento com foco nas habilidades menos desenvolvidas pelos alunos nas disciplinas de Língua Portuguesa e Matemática.

Duração: bimestralmente

Recursos necessários: Laboratório de Informática e cadernos de testes

Equipe envolvida: Professores, coordenador pedagógico e diretores.

\section{Casos de sucesso}

O projeto Amadis ocorreu no âmbito do Programa ECSIC- Escola, Conectividade e Sociedade da Informação e do Conhecimento. Este Programa, realizado em 2003/2004, constituiu-se numa parceria entre a UFRGS e a Prefeitura de Porto Alegre, com o apoio financeiro do BNDES, para elaborar, aplicar e testar modelos de metodologias, recursos pedagógicos e recursos informáticos para a educação, introduzindo inovações na Escola.

O ambiente AMADIS serviu de apoio ao desenvolvimento de experiências potencializadoras da inclusão digital e das aprendizagens nas mais diversas áreas do conhecimento (ciências naturais e sociais, matemática, tecnologia, língua, artes), realizadas sob a forma de Projetos de Aprendizagem, em 25 escolas da rede municipal de ensino, envolvendo 600 professores e 5000 alunos de classes de ensino básico. Para avaliação das inovações propostas pelo projeto ECSIC assim como da adequação do AMADIS como apoio às essas inovações, foram eleitas quatro categorias, posteriormente desdobradas em indicadores. 1. 
Conectividade, considerada como apropriação dos recursos interativos do ambiente e expressas pelo uso desses recursos na realização dos projetos; 2. Inovações nas práticas pedagógicas com o uso da tecnologia, expressas pela incorporação de práticas de Projetos de aprendizagem;3. Sustentabilidade das inovações, compreendida como possibilidade de continuidade de uso do Amadis e do trabalho com Projetos após a finalização do Programa ECSIC e 4. Recursos para apoio ampliado do trabalho com projetos de aprendizagem

Este artigo vislumbra um momento futuro de avaliação com uso de dados mais precisos. Mas no momento de sua publicação já era possível afirmar que o uso do Amadis para apoio aos Projetos de aprendizagem, mostrou que o ambiente favoreceu a introdução e/ou a consolidação de práticas construtivistas, apoiando 0 desenvolvimento de Projetos de Aprendizagem, em todos os níveis de ensino, conforme apontam os estudos realizados sobre os processos e produtos registrados no ambiente e nas observações realizadas in loco nas escolas.

Artigo disponível no endereço eletrônico abaixo http://www.bie.org/pub/index.php/rbie/article/view/37. Acessado em 23/09/2014.

\section{Novidade trazida pelo projeto}

O projeto que esta sendo proposto aqui, na verdade, é bem menor do que esse projeto utilizado como exemplo de sucesso. Será realizado no âmbito de uma escola e traz como foco específico a recuperação de estudos. E principalmente, tem como meta melhorar o desempenho da escola em avaliações externas. 0 projeto AMADIS visa potencializar o ensino de diversas disciplinas e inclui em sua proposta um ambiente de apoio ao professor. As oficinas de aprendizagem propostas neste projeto priorizam as disciplinas de Língua Portuguesa e Matemática. Embora nada impeça que sejam desenvolvidos materiais para outras disciplinas e a inclusão de outras disciplinas na plataforma de aprendizagem da escola. Os projetos se assemelham no objetivo de tornar as aulas mais atrativas e com a introdução das tecnologias disponíveis à educação.

\section{Cronograma de execução}

\begin{tabular}{|c|c|c|c|c|c|c|c|c|c|c|c|c|c|}
\hline \multirow{2}{*}{\multicolumn{2}{|c|}{ Atividades }} & \multicolumn{4}{|c|}{ Ano 1} & \multicolumn{4}{|c|}{ Ano 2} & \multicolumn{4}{|c|}{ Ano 3} \\
\hline & & \multirow{2}{*}{$\begin{array}{c}\text { Jan- } \\
\text { Fev } \\
\text { Mar } \\
\end{array}$} & \multirow{2}{*}{$\begin{array}{l}\text { Abr- } \\
\text { Mai- } \\
\text { Jun }\end{array}$} & \multirow{2}{*}{$\begin{array}{l}\text { Jul- } \\
\text { Ago } \\
\text { Set }\end{array}$} & \multirow{2}{*}{$\begin{array}{l}\text { Out- } \\
\text { Nov } \\
\text { Dez }\end{array}$} & $\begin{array}{l}\text { Jan- } \\
\text { Fev } \\
\text { Mar }\end{array}$ & $\begin{array}{l}\text { Abr- } \\
\text { Mai- } \\
\text { Jun }\end{array}$ & $\begin{array}{l}\text { Jul- } \\
\text { Ago } \\
\text { Set }\end{array}$ & $\begin{array}{l}\text { Out- } \\
\text { Nov } \\
\text { Dez }\end{array}$ & $\begin{array}{l}\text { Jan- } \\
\text { Fev } \\
\text { Mar }\end{array}$ & $\begin{array}{l}\text { Abr- } \\
\text { Mai- } \\
\text { Jun }\end{array}$ & $\begin{array}{l}\text { Jul- } \\
\text { Ago } \\
\text { Set }\end{array}$ & $\begin{array}{l}\text { Out- } \\
\text { Nov } \\
\text { Dez }\end{array}$ \\
\hline \multirow{3}{*}{ Etapa 1} & AIIV. 1.1 & & & & & & & & & & & & \\
\hline & Ativ. 1.2 & & & & & & & & & & & & \\
\hline & Ativ. 1.3 & & & & & & & & & & & & \\
\hline \multirow{2}{*}{ Etapa 2} & Ativ. 2.1 & & & & & & & & & & & & \\
\hline & Ativ. 2.2 & & & & & & & & & & & & \\
\hline \multirow{3}{*}{ Etapa 3} & Ativ. 3.1 & & & & & & & & & & & & \\
\hline & Ativ. 3.2 & & & & & & & & & & & & \\
\hline & Ativ. 3.3 & & & & & & & & & & & & \\
\hline
\end{tabular}




\section{Gestão estratégica}

\section{Objetivos estratégicos.}

\begin{tabular}{|c|c|c|c|}
\hline Objetivos & Metas & Indicadores & Acompanhamento \\
\hline \multirow{3}{*}{$\begin{array}{c}\text { Aumentar a } \\
\text { quantidade de } \\
\text { habilidades } \\
\text { adquiridas em } \\
\text { Língua } \\
\text { Portuguesa e } \\
\text { Matemática no } 9 \\
\text { ano de } \\
\text { escolaridade }\end{array}$} & $\begin{array}{l}\text { Aumentar o número de } \\
\text { aprovações nas respectivas } \\
\text { disciplinas em } 20 \% \text { ao final do } \\
\text { primeiro ano de projeto; } 30 \% \text { no } \\
\text { segundo ano e } 40 \% \text { no terceiro. }\end{array}$ & $\begin{array}{l}\text { Notas obtidas pelos } \\
\text { alunos no final de } \\
\text { cada ano em atas do } \\
\text { conselho de classe. }\end{array}$ & $\begin{array}{c}\text { Controle do rendimento da turma em } \\
\text { atas de conselho bimestral para que } \\
\text { haja um planejamento de ações } \\
\text { corretivas. }\end{array}$ \\
\hline & $\begin{array}{l}\text { Alcançar a meta estabelecida na } \\
\text { avaliação externa Prova Brasil } \\
\text { para Língua Portuguesa e } \\
\text { Matemática até o final do projeto. }\end{array}$ & $\begin{array}{l}\text { O Resultado de } 4,5 \\
\text { da avaliação externa } \\
\text { Prova Brasil para o } \\
\text { ano de } 2017 .\end{array}$ & $\begin{array}{c}\text { Análise bimestral de habilidades } \\
\text { apresentadas na avaliação } \\
\text { diagnóstica bimestral SAERJINHO, } \\
\text { para que haja uma recuperação } \\
\text { efetiva de estudos caso haja } \\
\text { necessidade. }\end{array}$ \\
\hline & $\begin{array}{c}\text { Tornar as oficinas de } \\
\text { aprendizagem um importante } \\
\text { instrumento de recuperação de } \\
\text { estudos }\end{array}$ & $\begin{array}{l}\text { O número de alunos } \\
\text { participantes das } \\
\text { oficinas }\end{array}$ & $\begin{array}{c}\text { Controle do nível de proeficiência } \\
\text { obtido nas avaliações diagnósticas } \\
\text { bimestrais }\end{array}$ \\
\hline $\begin{array}{l}\text { Diminuir a } \\
\text { quantidade de } \\
\text { professores e } \\
\text { alunos em } \\
\text { absenteísmo } \\
\text { escolar }\end{array}$ & $\begin{array}{l}\text { Diminuir em } 30 \% \text { o numero de } \\
\text { professores com atrasos e faltas } \\
\text { no primeiro ano, } 40 \% \text { do segundo } \\
\text { ano, } 50 \% \text { no terceiro ano de } \\
\text { projeto. } \\
\text { Diminuir em } 30 \% \text { o numero de } \\
\text { alunos em absenteísmo escolar } \\
\text { no primeiro ano do projeto, } 40 \% \\
\text { no segundo ano, } 50 \% \text { no terceiro } \\
\text { ano do projeto }\end{array}$ & $\begin{array}{c}\text { O número de } \\
\text { professores faltosos } \\
\text { e em situação de } \\
\text { atraso. } \\
\text { O número de alunos } \\
\text { faltosos e com } \\
\text { atrasos nas aulas }\end{array}$ & $\begin{array}{l}\text { Controle quinzenal da frequência } \\
\text { escolar para evitar ausências } \\
\text { superiores a dez dias consecutivos } \\
\text { ou interpolados. }\end{array}$ \\
\hline $\begin{array}{l}\text { Tornar as aulas de } \\
\text { Língua Portuguesa } \\
\text { e Matemática } \\
\text { mais atrativas }\end{array}$ & $\begin{array}{c}\text { Aumentar em } 30 \% \text { a utilização } \\
\text { dos laboratórios de informática e } \\
\text { vídeo no primeiro ano, } 40 \% \text { no } \\
\text { segundo, } 50 \% \text { no terceiro ano do } \\
\text { projeto. }\end{array}$ & $\begin{array}{l}\text { Número de aulas } \\
\text { dadas nos } \\
\text { laboratórios de } \\
\text { informática e vídeo }\end{array}$ & $\begin{array}{l}\text { Análise bimestral do relatório de } \\
\text { controle dos laboratórios }\end{array}$ \\
\hline
\end{tabular}

\section{Continuidade do projeto}

0 foco das oficinas de aprendizagem é a recuperação de estudos com o objetivo de alcançar as metas estabelecidas para o Ideb e nas avaliações estaduais Saerj. 0 tempo inicial previsto é de 01 a 03 anos, porém é possível dar continuidade com menos recursos. Para a manutenção do projeto, é necessária a contratação de um técnico em informática e nas TIC's e uma atualização da plataforma de aprendizagem anualmente. Caso haja necessidade, uma reforma do laboratório com trocas de equipamentos. Os professores novos na escola também necessitam de capacitação e treinamento. Acredito ser possível fazer a manutenção do projeto com os recursos mensais que a escola possui e que são repassados pela Secretaria de Estado de Educação. 
O projeto é ambicioso porque caso a previsão de resultados positivos na recuperação de estudos se confirme durante o projeto, ele pode ser ampliado para outras disciplinas e transformar a recuperação de estudos da escola que atualmente mostra suas fragilidades em algo prazeroso com a utilização das oficinas de aprendizagem mediadas pelo uso de tecnologia.

A preocupação com os resultados obtidos nas avaliações externas e internas e sua prováveis causas deve ser prioridade da escola. Como também uma reflexão com ação sempre que o sinal amarelo aparecer. Um sinal que algo não vai bem e que os alunos não estão aprendendo como deveriam. $E$ preciso incluir 0 aluno na escola, mas com qualidade e garantia de permanência.

\section{Marketing e comunicação}

\section{Lançamento do projeto}

Em todo o início de ano letivo, há tradicionalmente uma semana pedagógica. Durante essa semana, e de preferência no acolhimento dos professores, será feito o lançamento do projeto. Oficinas de aprendizagem. Antes da apresentação do passo-a-passo do projeto inovador para a nossa escola, será feito uma apresentação da escola com sua missão e valores e da visão de futuro. Todos devem estar cientes dos valores da organização que trabalham. Caso haja dúvidas ou falta de comprometimento de alguns membros em relação as propostas da escola, esse fator pode acarretar um resultado abaixo do esperado. Os últimos resultados apresentados pela escola nas avaliações externas e internas e os desvios apresentados em relação aos objetivos da escola precisam ser discutidos. A missão, os valores e a visão de futuro da organização podem ser reavaliados periodicamente. E esse momento é oportuno.

Os recursos utilizados para que esse dia de acolhimento e apresentação do projeto sejam um sucesso, passam por uma comunicação inicial por email, visto que os professores estarão de férias, convocando-os e ressaltando a importância de cada um para organização de mais ano letivo. Uma apresentação da escola através da lousa digital e uso de computador portátil. Material impresso para leitura e um banner. Neste momento, está previsto o lançamento apenas para os membros internos da organização. Em um segundo momento, o projeto será lançado para a comunidade e possíveis colaboradores. Para esse momento, será necessário, a entrega de convites individualizados e programado um café da manhã para tornar o clima favorável a troca de idéias e recebimento de propostas de parcerias. Utilizando os recursos de tecnologia do encontro anterior. E com previsão para acontecer uma semana após o primeiro encontro.

\section{Canais de comunicação e acompanhamento do projeto}

\section{Marketing interno}

O lançamento do projeto é apenas o início da jornada a ser percorrida para que o projeto se firme como uma proposta efetiva de recuperação de estudos. Além disso, será necessária uma comunicação interna muito bem estruturada. Com o uso do correio eletrônico a cada 15 dias, cartazes pela escola e boletins com uma periodicidade contendo novas informações e fotos a cada novo mês.

$O$ treinamento em serviço dos professores, coordenadores e diretores escolares no inicio do ano letivo e a cada seis meses para que a proposta de uso das oficinas de aprendizagem com uso de tecnologia seja entendida e apropriada por todos torna-se fundamental para agregar todos entorno do projeto e como uma forma de valorização da equipe.

\section{Marketing externo}

A realidade local mostra que a comunicação via bilhetes e cartas por escrito aos pais não tem um grande alcance. Talvez, pelo fato dos pais terem pouca escolaridade como foi mostrado no diagnóstico da escola e ou por trabalharem muito fora de casa ficando com pouco tempo para acompanhar o seu filho na escola. 0 resultado um pouco melhor alcançado em outros momentos onde se fez necessária a comunicação entre família e escola, foram as ligações telefônicas. Portanto, a comunicação por essa via se fará presente em todas as comunicações externas. 
Um banner em frente à escola, mostrando de forma resumida e informando o objetivo das oficinas de aprendizagem, público alvo e horários que serão realizados os encontros provocará uma melhor visualização pela comunidade em geral.

Podemos contar com um agente visitador às famílias em que os filhos não compareçam as oficinas com o objetivo de trazer esse aluno para a escola e conscientizar os pais da importância do projeto.

\section{Parceiros estratégicos}

Um dos principais parceiros previstos são as Universidades Públicas e Particulares do Municípios de Niterói e São Gonçalo. O papel desses parceiros no projeto Oficinas de aprendizagem é fornecer alunos estagiários que atuarão como orientadores aos alunos da escola nos momentos das oficinas. $O$ auxilio em relação ao conteúdo e ao uso das ferramentas de tecnologia e de comunicação será necessário em todos os encontros. A escola, como contrapartida fornecerá às Universidades um espaço fértil para a realização de pesquisas e prática do estágio, componente obrigatório para a formação dos alunos de licenciatura.

Para obter a adesão ao projeto pretendemos agendar visitas as Universidades e levar pessoalmente o projeto oferecendo a nossa proposta de parceria e benefícios e uma apresentação de Power Point mostrando a escola e o seu espaço físico. Neste momento e caso haja interesse, poderemos agendar uma visita de volta a escola para que os possíveis parceiros possam sentir o impacto visual que a escola pode oferecer.

\section{Divulgação de resultados}

0 projeto inovador aqui proposto tem a previsão inicial de duração de 01 a 03 anos, porém é necessário avaliar os resultados parciais obtidos pelo projeto. O início do ano letivo é uma excelente oportunidade. Neste momento ainda não teremos os resultados da avaliação externa estadual SAERJ, que apenas são publicados no segundo bimestre do ano seguinte a sua realização. Porém, os resultados do ano anterior já podem ser consultados através dos relatórios internos.

A reunião de retorno dos professores e funcionários após o primeiro ano de implementação do projeto será fundamental para firmar a parceria e 0 apoio da equipe. Como também avaliar os resultados obtidos e possíveis ajustes ao projeto. Neste momento, utilizaremos as planilhas atualizadas com resultados por disciplina e 0 índice de evasão escolar referente ao $9^{\circ}$ ano de escolaridade. Não deixando de priorizar os resultados em Língua Portuguesa e Matemática. A apresentação dos resultados contará com recursos visuais, como fotos e os gráficos. A lousa digital e um computador serão necessários neste momento.

\section{Equipe do projeto}

\section{Equipe interna}

\begin{tabular}{|c|c|c|c|c|}
\hline Cargo & Formação & $\begin{array}{c}\text { Tempo na } \\
\text { escola }\end{array}$ & Experiência anterior & $\begin{array}{c}\text { Responsável pelas } \\
\text { atividades: }\end{array}$ \\
\hline $\begin{array}{c}\text { Professores } \\
\text { regentes }\end{array}$ & Nível superior & 15 anos & $\begin{array}{c}\text { Professores de escolas } \\
\text { públicas e particulares da } \\
\text { região }\end{array}$ & $\begin{array}{c}1.1,1.21 .3,2.1,2.2, \\
3.1,3.2,3.3\end{array}$ \\
\hline $\begin{array}{c}\text { Coordenador } \\
\text { Pedagógico }\end{array}$ & $\begin{array}{c}\text { Nível superior } \\
\text { Especialização }\end{array}$ & 10 anos & $\begin{array}{c}\text { Professor da rede pública } \\
\text { da região }\end{array}$ & $\begin{array}{c}1.1,1.2,1.3,2.1,2.2, \\
3.1,3.2,3.3\end{array}$ \\
\hline Gestor Escolar & $\begin{array}{c}\text { Nivel Superior } \\
\text { Especialização em } \\
\text { gestão }\end{array}$ & 08 anos & $\begin{array}{c}\text { Gestor da rede pública } \\
\text { Estadual }\end{array}$ & $1.1,1.2,1.3,3.1,3.2,3.3$ \\
\hline Secretário Escolar & Nível Superior & 15 anos & Auxiliar Administrativo & 3.1 \\
\hline
\end{tabular}

\section{Profissionais externos}

\begin{tabular}{|l|c|c|}
\hline Tipo de profissional & Competências necessárias & Participação no projeto \\
\hline Especialista em TICs & Nivel superior & $\begin{array}{c}\text { Elaboração da plataforma de aprendizagem e } \\
\text { capacitação dos professores para o seu uso. }\end{array}$ \\
\hline
\end{tabular}




\section{Recuperação de estudos: Uma busca pela educação de qualidade}

\section{Plano financeiro}

Investimentos (despesas de capital)

\begin{tabular}{|c|c|c|c|}
\hline Obras e infraestrutura & Ano 1 & Ano 2 & Ano 3 \\
\hline OBRAS & $4.000,00$ & $2.000,00$ & $2.000,00$ \\
\hline INSTALAÇÕES & $3.000,00$ & $2.000,00$ & $4.000,00$ \\
\hline Total & $\mathbf{7 . 0 0 0 , 0 0}$ & $4.000,00$ & Ano 3 \\
\hline Material permanente & Ano 1 & Ano 2 & $1.500,00$ \\
\hline EQUIPAMENTOS & $6.000,00$ & $4.500,00$ & $3.500,00$ \\
\hline COMPUTADORES & $7.000,00$ & $3.500,00$ & $\mathbf{5 . 0 0 0 , 0 0}$ \\
\hline Total & $13.000,00$ & $\mathbf{8 . 0 0 0 , 0 0}$ & \\
\hline
\end{tabular}

\section{Despesas correntes}

\begin{tabular}{|c|c|c|c|}
\hline Material de consumo & Ano 1 & Ano 2 & Ano 3 \\
\hline Pen drive & 1200,00 & 1272,00 & 1348,32 \\
\hline Cd's & 240,00 & 254,40 & 269,66 \\
\hline Dvd's & 240,00 & 254,40 & 269,66 \\
\hline Resmas de papel A4 & 960,00 & 1017,60 & 1078,65 \\
\hline Cartuchos para impressora & 1440,00 & 1526,40 & 1617,98 \\
\hline Total & $4.080,00$ & $4.324,80$ & $4.584,28$ \\
\hline Gastos com locomoção & Ano 1 & Ano 2 & Ano 3 \\
\hline Passagens e locomoção & $1.200,00$ & $1.272,00$ & $1.348,32$ \\
\hline Total & $1.200,00$ & $1.272,00$ & $1.348,32$ \\
\hline Serviços de terceiros & Ano 1 & Ano 2 & Ano 3 \\
\hline Técnico em TI & $4.320,00$ & $4.579,20$ & $4.853,95$ \\
\hline Padaria e confeitaria & $1.200,00$ & $1.272,00$ & $1.348,32$ \\
\hline Total & $5.520,00$ & $5.851,20$ & $6.202,27$ \\
\hline
\end{tabular}


Flávia Gonçalves da Silva Mendes

\section{Recursos do edital}

\begin{tabular}{|c|c|c|c|c|}
\hline Tipo de item & Ano 1 & Ano 2 & Ano 3 & Total \\
\hline Despesas de Capital & $\mathbf{2 0 , 0 0 0 , 0 0}$ & $\mathbf{1 2 . 0 0 0 , 0 0}$ & $\mathbf{9 . 0 0 0 , 0 0}$ & $\mathbf{4 1 . 0 0 0 , 0 0}$ \\
\hline Obras e infraestrutura & $7.000,00$ & $4.000,00$ & $4.000,00$ & $15.000,00$ \\
\hline Material permanente & $13.000,00$ & $8.000,00$ & $5.000,00$ & $26.000,00$ \\
\hline Despesas Correntes & $\mathbf{1 0 . 8 0 0 , 0 0}$ & $\mathbf{1 1 . 4 4 8 , 0 0}$ & $\mathbf{1 2 . 1 3 4 , 8 8}$ & $\mathbf{3 4 . 3 8 2 , 8 8}$ \\
\hline Material de consumo & $4.080,00$ & $4.324,80$ & $4.584,29$ & $12.989,09$ \\
\hline Gastos com locomoção & $1.200,00$ & $1.272,00$ & 1348,32 & $3.820,32$ \\
\hline Serviços de terceiros & $5.520,00$ & $5.851,20$ & $6.202,27$ & $17.573,47$ \\
\hline Total do projeto & $\mathbf{3 0 . 8 0 0 , 0 0}$ & $\mathbf{2 3 . 4 4 0 , 0 0}$ & $\mathbf{2 1 . 1 3 4 , 8 8}$ & $\mathbf{7 5 . 3 8 2 , 8 8}$ \\
\hline
\end{tabular}

\begin{tabular}{|c|c|c|c|c|}
\hline \multicolumn{4}{|c|}{ Cálculo da Necessidade de Recursos } & \\
\hline Item & ANO 1 & ANO 2 & ANO 3 & TOTAL \\
\hline I. Total das Despesas Correntes & $10.800,00$ & $11.448,00$ & $12.134,88$ & $34.382,88$ \\
\hline Material de Consumo & $4.080,00$ & $4.324,80$ & $4.584,29$ & $12.989,09$ \\
\hline Passagens e Despesas com Locomoção & $1.200,00$ & $1.272,00$ & $1.348,32$ & $3.820,32$ \\
\hline Serviços de Terceiros & $5.520,00$ & $5.851,20$ & $6.202,27$ & $17.573,47$ \\
\hline II. Total de Despesas Administrativas & $9.600,00$ & $10.176,00$ & $10.786,56$ & $30.562,56$ \\
\hline III. Total de Despesas com Pessoal & $11.014,56$ & $11.675,43$ & $12.375,96$ & $35.065,95$ \\
\hline IV. Total de Despesas de Capital (investimentos) & $20.000,00$ & $12.000,00$ & $9.000,00$ & $41.000,00$ \\
\hline Necessidade de Recursos (I+II+III+IV) & $51.414,56$ & $45.299,43$ & $44.297,40$ & $141.011,39$ \\
\hline Recursos Edital & $30.800,00$ & $23.448,00$ & $21.134,88$ & $75.382,88$ \\
\hline Recursos da Organização (contrapartida) & $20.614,56$ & $21.851,43$ & $23.162,52$ & $65.628,51$ \\
\hline
\end{tabular}

O projeto "Oficinas de Aprendizagem" atende as exigências do Edital, e traz consigo a possibilidade de mudar a forma como a recuperação de estudos é realizada em nossa escola e fazer com que haja uma melhoria significativa da qualidade de ensino. É importante que aluno tenha acesso à escola, mas que nela aprenda 0 suficiente para participar da vida social e ingressar no mundo do trabalho com êxito, permaneça nela até 0 término do Ensino Médio e com perspectivas de cursar o Ensino Superior. Portanto toda a sociedade ganha, quando a escola tem um ensino de qualidade. 